DOI:10.15740/HAS/IJAS/13.1/159-160

\title{
Effect of foliar sprays of water soluble fertilizer, growth regulator and micronutrients on yield and quality of soybean
}

\author{
P. B. ZAMBRE*, P. T. KOLEKAR AND S. R. UGHADE \\ Department of Agronomy, Mahatma Phule Krishi Vidyapeeth, Rahuri, AHMEDNAGAR (M.S.) INDIA
}

\begin{abstract}
A field experiment was conducted during Kharif seasons of 2012, at Mahatma Phule Krishi Vidyapeeth, Rahuri, dist. Ahmednagar to study effect of foliar sprays of water soluble fertilizer, growth regulator and micronutrients on yield and quality of soybean. Significantly higher grain yield $\left(22.70 \mathrm{q} \mathrm{ha}^{-1}\right)$ and straw yield $\left(21.00 \mathrm{q} \mathrm{ha}^{-1}\right)$ was obtained in treatment GRDF + foliar spray of 19:19:19 NPK $0.5 \%+\mathrm{H}_{3} \mathrm{BO}_{3} 0.5 \%+\mathrm{ZnSO}_{4} 0.5 \%$ at 30 and 40 DAS. Among the treatment highest protein content (38.54\%) and oil content (19.14\%) was obtained in treatment GRDF + foliar spray of 19:19:19 NPK 0.5\% $+\mathrm{H}_{3} \mathrm{BO}_{3} 0.5 \%+\mathrm{ZnSO}_{4} 0.5$ $\%$ at 30 and 40 DAS.
\end{abstract}

Key Words : Foliar spray, Soybean, Water Soluble fertilizer, Micronutrient, Growth regulator

View Point Article : Zambre, P.B., Kolekar, P.T. and Ughade, S.R. (2017). Effect of foliar sprays of water soluble fertilizer, growth regulator and micronutrients on yield and quality of soybean. Internat. J. agric. Sci., 13 (1) : 159-160, DOI:10.15740/HAS/IJAS/13.1/159160.

Article History : Received : 07.10.2016; Accepted : 30.12.2016 